\title{
PENERAPAN MODEL PEMBELAJARAN QUANTUM TEACHING AND LEARNING UNTUK MENINGKATKAN HASIL BELAJAR IPA SISWA KELAS III SD
}

\author{
Yullinar R. Podomi ${ }^{1, *}$, Supit Pusung ${ }^{2}$, Juliana M. Sumilat ${ }^{3}$, Fientje J. A. Oentoe, Hetty J. Tumurang ${ }^{4}$ \\ ${ }^{1}$ Universitas Negeri Manado \\ *Email: yullinarpodomi22@gmail.com
}

\begin{abstract}
Abstrak
Pembelajaran sains di sekolah dasar sangat menantang karena banyak peristiwa alam yang belum dipahami siswa. Prinsip utama dari model pengajaran quantum bawalah dunia mereka ke dunia kita dan hantarkan dunia kita masuk ke dunia mereka, mampu membuat para siswa sekolah dasar tertarik untuk belajar dan memahami beberapa peristiwa yang baru untuk siswa kelas 3 SD. Tujuan penelitian ini adalah menganalisis penerapan model pembelajaran Quantum teaching and learning untuk meningkatkan hasil belajar siswa pada mata pelajaran IPA kelas III SD. Penelitian ini dilakukan di Sekolah Dasar Walian 4/82 dengan subjek penelitian siswa kelas 3. Teknik pengumpulan data dilakukan dengan tes hasil belajar ulang dan dianalisis dengan perhitungan ketuntasan belajar. Hasil penelitian ini menunjukkan penerapan model pengajaran quntum dapat meningkatkan hasil belajar siswa pada mata pelajaran IPA, dimana dalam pembelajaran ini siswa di buat penasaran dan guru menghantarkan siswa dengan situasi yang membawa dunia mereka ke dalam dunia kita dan menghantarkan dunia kita ke dalam dunia mereka, sehingga meningkatkan minat belajar yang bersinergi pada peningkatan hasil belajar.
\end{abstract}

Kata Kunci: Model Quantum Teaching and Learning Hasil Belajar IPA

\begin{abstract}
Learning science in elementary school is very challenging because many introduce events that have not been understood students. The main principle of the quantum teaching model is "bring their world into our world and let our world into their world" is able to make the elementary school students interested to learn and understand some of the events that are new knowledge for grade 3 elementary students. The purpose of this study is to analyze the application of Quantum teaching learning model to improve student learning outcomes in science subjects class III elementary school. This research was conducted at 4/82 Walian Elementary School with research subjects of 3 rd grade students. Technique of collecting data is done with result of learning test and analyzed with calculation of mastery learn. The results of this study show the application of quntum teaching model can improve student learning outcomes in science subjects, where in this learning students are made curious and teachers deliver students to situations that bring their world into our world and deliver our world into their world, thus increasing interest in learning that synergizes in improving learning outcomes
\end{abstract}

Keywords: Science, Learning Outcomes, Quantum Teaching Model 


\section{Pendahuluan}

Dalam undang-undang No. 20 Tahun 2003 Pendidikan Nasional menyatakan bahwa pendidikan adalah usaha dasar dan terencana untuk mewujudkan suasana belajar dan proses pembelajaran agar peserta didik secara aktif mengembangkan potensi dirinya untuk memiliki kekuatan spiritual keagamaan pengendalian dirinya, masyarakat, bangsa dan Negara. Pendidikan memegang peran penting dalam upaya meningkatkan sumber daya manusia, pendidikan juga merupakan satu aspek kehidupan yang sangat mendasar bagi pembangunan bangsa dan negara, karena pendidikan adalah akar dari suatu negara. Pada penyelenggaraan pendidikan di sekolah yang melibatkan guru dan siswa diwujudkan dengan adanya proses pembelajaran.

Ilmu Pengetahuan Alam (IPA) sebagai salah satu mata pelajaran di sekolah dinilai cukup memegang peranan penting dalam membentuk siswa menjadi berkualitas dan IPA di Sekolah Dasar adalah mata pelajaran yang menanamkan dan mengembangkan pengetahuan, keterampilan, sikap dan nilai ilmiah pada siswa serta rasa mencintai dan menghargai kebesaran Tuhan Yang Maha Esa. Tujuan IPA secara umum membantu agar siswa memahami konsep-konsep sains dan keterkaitanya dengan kehidupan sehari-hari, karna itu perlu adanya peningkatan mutu pendidikan IPA.Salah satu hal yang harus diperhatikan adalah peningkatan hasil belajar IPA siswa di sekolah.

Namun pada saat melakukan observasi di SD Inpres 4/82 Walian, masalah yang didapatkan didalam kelas yaitu masih banyak siswa tidak mencapai Kriteria Ketuntasan Minimal (KKM).

Hal ini tampak dari 14 siswa hanya 6 siswa yang mencapai KKM dan 8 orang diantaranya tidak mencapai KKM, ini disebabkan karna guru tidak menggunakan metode yang tepat serta pada saat pembelajaran guru tidak menggunakan media pembelajaran yang mampu merangsang rasa ingin tahu dari para siswa, sehingga pada saat pembelajaran kelas menjadi tidak fokus yang mengakibatkan minat belajar siswa berkurang. Kemudian guru juga belum maksimal mengelola pembelajaran sehingga terlihat sebagian siswa hanya asik bermain dan mengganggu teman lainya dikelas dan berdampak pada hasil belajar yang belum mampu mencapai KKM. Proses pembelajaran yang melibatkan peran siswa secara aktif dalam kegiatan pembelajaran dapat membuat siswa-siswa mencapai hasil belajar yang optimal. Salah satu model pembelajaran yang melibatkan peran siswa secara aktif adalah model pembelajaran Quantum Teaching and Learning.

Model pembelajaran Quantum Teaching and Learning cocok diterapkan pada pembelajaran IPA, karna dalam pembelajaran IPA tidak cukup hanya dengan mengetahui dan menghafalkan tetapi juga dibutuhkan suatu pemahaman serta kemampuan mengaplikasikan dalam kehidupan sehari-hari. Model pembelajaran Quntum Teaching and learning merupakan salah satu model pembelajaran yang dapat membuat siswa merasa nyaman dan gembira dalam belajar. Karena model ini akan membuat setiap siswa untuk selalu aktif dalam proses belajar. Model pembelajaran Quntum Teaching and learning adalah konsep yang menguraikan cara-cara baru dalam memudahkan proses pembelajaran, lewat panduan unsur seni dan pencapaianpencapaian yang terarah, apapun mata pelajaran yang diajarkan. (DePorter, 2010:32)

Asas utama dari model pembelajaran Quntum Teaching and learning yang diuraikan DePorter dkk (2010:34) adalah "bawalah dunia mereka ke dunia kita dan antarkan dunia kita ke dunia mereka." Asas dari model pembelajran ini mampu menciptakan lingkungan belajar yang efektif, dengan cara menggunakan unsur yang ada pada siswa dan lingkungan belajarnya melalui interaksi yang terjadi didalam kelas dan menghubungkan dengan konsep materi yang diajarkan. 
Selanjutnya pada model ini juga diberikan penghargaan atau perayaan dari pengetahuan yang diperoleh siswa sebagai feedback positif terhadap usaha siswa selama proses pembelajaran. Dengan melakukan kegiatan perayaan mampu memberikan motivasi untuk semakin giat belajar. Demikian juga dengan hasil penelitian Dewi (2014:11) dan kawan-kawan yang menyimpulkan bahwa terdapat perbedaan hasil belajar IPA antara siswa yang dibelajarkan dengan model pembelajaran quantum teaching and lerning tipe TANDUR dengan model pembelajaran konvensional, dan model pembelajaran quantum teaching and lerning tipe TANDUR memiliki pengaruh terhadap hasil belajar IPA siswa kelas V SD.

Berdasarkan latar belakang masalah di atas yang menjadi rumusan masalah penelitian adalah: Apakah penerapan model pembelajaran Quantum Teaching and Learning dapat meningkatkan hasil belajar IPA siswa kelas III SD Inpres 4/82 Walian?

\subsection{Model Pembelajaran Quantum Teaching And Learning.}

Kata Quantum sendiri berarti interaksi yang mengubah energi menjadi cahaya artinya mengubah hambatan-hambatan pembelajaran menjadi cahaya yang bermanfaat bagi siswa, Teaching diperuntukan untuk guru dan Learning diperuntukan untuk siswa. Quantum Teaching and Learning adalah ilmu pengetahuan dan metodologi yang digunakan dalam rancangan penyajian, dan fasilitas Supercamp yang diciptakan berdasarkan teoriteori pendidikan.Selain itu Quantum Teaching and Learning juga dapat diartikan sebagai pendekatan pengajaran untuk membimbing peserta didik agar mau belajar. Disamping itu untuk memotivasi, menginspirasi dan membimbing guru agar lebih efektif dan sukses dalam pembelajaran sehingga lebih menarik dan menyenangkan. Quantum Teacing and Learning menawarkan suatu sintesis dari hal-hal yang dicari, atau cara-cara baru memaksimalkan dampak usaha pengajaran yang dilakukan guru (DePorter,2010:32). Model pembelajaran Quantum Teaching and Learning adalah model pembelajaran yang didasarkan pada pendekatan yang menggunakan keberagaman pengetahuan peserta didik yang termasuk pada prinsip teori multiple intelegence dengan memperhatikan perkembangan fisik dan mental peserta didik (Acat dan Yusuf, 2014: 13). Selanjutnya Hanbay (2009:19) menyatakan bahwa tujuan utama dari model pembelajaran ini adalah memberikan kesempatan pada peserta didik untuk mengaktualisasikan dirinya secara keseluruhan dalam proses pembelajaran. Asas dari Model pembelajaran Quantum Teaching and Learning adalah bawalah dunia kita (guru) ke dunia mereka (peserta didik) dan hantarkan dunia mereka ke dunia kita (DePorter, 2010:10)

\subsection{Langkah-langkah Model Pembelajaran}

Model pembelajaran Quantum Teaching and learning memiliki beberapa tipe pembelajaran, namun dalam penelitian ini menggunakan model pembelajaran Quantum Teaching and learning tipe TANDUR yang dikemukakan oleh DePorter (2010:10). Adapun langkah-langkahnya diuraikan sebagai berikut.

1) Tumbuhkan

Konsep tumbuhkan ini sebagai konsep oprasional dari prinsip "bawalah dunia mereka ke dunia kita”. Dengan usaha menyertakan siswa dalam pikiran dan emosinya, sehingga tercapai jalinan dan kepemilikan bersama atau kemampuan saling memahami.

Secara umum konsep tumbuhkan adalah sertakan diri mereka, puaskan keingintahuan, buatlah siswa tertarik atau penasaran tentang materi yang akan diajarkan. Dari hal tersebut tersirat, bahwa dalam pendahuluan (persiapan) pembelajaran 
dimulai guru menumbuhkan sikap positif dengan menciptakan lingkungan yang positif, lingkungan sosial (komunitas belajar), sarana belajar, serta tujuan yang jelas dan memberikan makna pada siswa, sehingga menimbulkan rasaingin tahu.

2) Alami

Tahap ini jika kita tulis pada tahap pelaksanaan pembelajaran terdapat pada kegiatan inti. Konsep "alami" mengandung pengertian bahwa dalam pembelajaran guru harus memberi pengalaman dan manfaat terhadap pengetahuan yang dibangun siswa sehingga menimbulkan hasrat alami otak untuk menjelajah.

Pada konsep alami guru memberikan cara terbaik agar siswa memahami informasi, memberikan permainan atau kegiatan yang memanfaatkan pengetahuan yang sudah merekamiliki, sehingga dapat memfasilitasi siswa untuk memperoleh pengetahuan yang melekat.

3) Namai

Konsep ini berada pada kegiatan inti, yang "namai" yang mengandung maksud bahwa menamaan memuaskan hasrat alami otak (membuat siswa penasaran, penuh pertanyaan mengenai pengalaman) untuk memberikan identitas, menguatkan dan mendefinisikan.Penamaan dalam hal ini adalah mengajarkan konsep, melatih keterampilan berpikir dan strategi belajar. Pertanyaan yang dapat memandu guru dalam memahami konsep "namai" yaitu perbedaan yang perlu dibuat dalam belajar, apa yang harus guru tambahkan pada pengertian siswa, strategi kiat jitu, alat berpikir yang digunakan untuk siswa ketahui atau siswa gunakan.

4) Demonstrasikan.

Tahap ini masih pada kegiatan inti, pada tahap ini adalah memberi kesampatan siswa untuk menunjukan bahwa siswa tahu. Hal ini sekaligus memberi kesempatan siswa untuk menunjukan tingkat pemahaman terhadap materi yang dipelajari.
Strategi yang dapat digunakan adalah mempraktekkan, melakukan percobaan, menyusun laporan, menganlisis data, melakukan gerakan tangan, kaki, gerakan tubuh bersama secara harmonis, dan lain-lain. 5) Ulangi

Tahap ini juka kita tuangkan pada rencana pelaksanaan pembelajaran terdapat pada penutup. Tahap ini dilaksanakan untuk memperkuat koneksi saraf dan menumbuhkan rasa "aku tahu bahwa aku tahu ini". Kegiatan ini dilakukan secara multimodalitas dan multi kecerdasan.

Guru memberikan ulangan tentang apa yang sudah dipelajari, strategi untuk mengimplementasikan yaitu bisa dengan membut isian "aku tahu bahwa aku tahu ini" hal ini merupakan kesempatan siswa untuk mengajarkan pengetahuan baru kepada orang lain (kelompok lain) atau dapat melakukan pertanyaan-pertanyaan post tes.

6) Rayakan.

Tahap ini dituangkan pada penutup pembelajaran. Dengan maksut memberikan rsa puas, untuk menghormati usaha, ketekunan, dan kesuksesan yang ahirnya memberikan rasa kepuasan dan kegembiraan.Strategi yang dapat digunakan adalah dengan pujian bernyayi bersama, pesta kelas, memberikan tepukan.

\subsection{Hasil Belajar}

Tujuan akhir dari suatu proses pembelajaran adalah hasil belajar. Sumilat (2018:41) menyatakan bahwa hasil belajar merupakan hasil yang diperoleh setelah melalui proses pembelajaran dalam bentuk perubahan tingkah laku yang dapat diukur, baik dalam bentuk pengetahuan, sikap dan keterampilan. Pengetahuan yang merupakan hasil belajar bukan hanya berdasarkan dari kemampuan awal siswa, namun terdapat pengaruh dari luar diri siswa yang berasal dari kecakapan dalam proses pembelajaran (Lucas et al,2008: 363). 
Hal senanda dinyatakan oleh Makmun, (2007:156) bahwa subyek yang terlibat dan bekerjasama dalam proses pembelajaran sehingga menghasilkan perubahan non fisik seperti sikap, pengetahuan dan kecakapan adalah guru dan siswa. Pendapat ini dikuatkan oleh pendapat Syah (2011:129) yang menjelaskan factor-faktor hasil belajar terdiri dari tiga yaitu 1) siswa itu sendiri (factor internal), 2) Faktor dari luar siswa (factor eksternal) seperti guru, dan 3) faktor pendekatan pembelajaran.

Berdasarkan uraian di atas maka disimpulkan bahwa hasil belajar merupakan perubahan non fisik pada diri siswa yang dapat diukur dan berbentuk pengetahuan, sikap, dan keterampilan serta faktor yang mempengaruhinya adalah kemampuan siswa itu sendiri dan pengaruh dari luar siswa yang berasal dari kecakapan dalam proses pembelajaran, seperti guru dan pendekatan pembelajaran.

\section{Metode Penelitian}

Penelitian ini menggunakan metode penelitian tindakan kelas (PTK) yang mengacu pada desain penelitian yang dikemukakan Kemmis dan Taggart yang terdiri atas empat tahap, yaitupersiapan/ perencanaan, pelaksanaan/ tindakan, observasi/ pengamatan, dan refleksi.

Subjek dalam penelitian ini adalah siswa di kelas III SD INPRES 4/82 Walian dengan jumlah 14 siswa terdiri atas 6 laki-laki dan 8 Perempuan.Pengumpulan data dilakukan dengan teknik observasi, dan tes. Teknik observasi dilakukan untuk mengetahui kegiatan siswa saat proses pembelajaran berlangsung. Sedangkan tes digunakan untuk mengetahui pencapaian hasil belajar, dengan menggunakan tes tulisan.

Analisis data dilakukan pada setiap akhir tindakan pada setiap siklus.Data yang diperoleh dari hasil observasi dan tes dianalisis dengan perhitungan presentasi hasil belajar yang dicapai siswa.Penentuan ketuntasan hasil belajar berdasarkan penilaian acuan patokan, yaitu sejauh mana kemampuan yang ditargetkan dapat dikuasai siswa dengan cara menghitung proporsi jumlah siswa yang tuntas dibagi dengan jumlah siswa seluruhnya.Setiap siswa dikatakan tuntas jika mendapatkan nilai hasil belajar minimal 70 , dan pembelajaran dikatakan tuntas jika $75 \%$ siswa memiliki nilai hasil belajar minimal 70 (Sumilat, 2018: 43). Perhitungan ketuntasan belajar klasikal mengunakan rumus sebagai beriukut:

Keterangan

$$
K B=\frac{T}{T t} \times 100 \%
$$

$\mathrm{KB}=$ Ketuntasan belajar

$\mathrm{T}=$ Jumlah siswa yang tuntas

$\mathrm{Tt}=$ Jumlah total siswa

\section{Hasil Penelitian dan Pembahasan 3.1. Hasil Penelitian}

Penelitian ini dilaksanakan dengan 2 siklus, yang masing-masing siklus terdiri dari tahapan perencanaan, pelaksanaan, observasi dan refleksi.

\section{Siklus 1.}

Pada siklus 1 ini, peneliti berkolaborasi dengan guru kelas untuk menyusun strategi dan rencana proses pembelajaran menggunakan model pembelajaran quantum teacing and learning dan selanjutnya peneliti menyiapkan materi ajar dan media pembelajaran serta alat evaluasi seperti lembar observasi, LKS dan lembar penilaian. Dari hasil observasi pelaksanaan tindakan siklus 1 diuraikan sebagai berikut.

Kegiatan pembelajaran dimulai dengan salam dan doa dimana guru menunjuk salah satu murid untuk memimpin doa, kemudian guru menumbuhkan minat belajar anak dengan memberikan motivasi belajar kemudian menyanyi bersama lagu delman istimewa dilanjutkan dengan guru menyampaikan tujuan pembelajaran yaitu siswa dapat menyebutkan dan memberikan contoh tentang 
macam-macam gerak benda disini guru terlihat cukup baik dalam menjelaskan kepada siswa.Guru kemudian masuk pada kegiatan inti pembelajaran yang dimulai dengan menumbuhkan sifat "alami" yaitu guru bertanya kepada siswa tentang gerak benda sesuai dengan pengalaman siswa seperti naik delman, bermain bola, menaiki perosotan dan pengalaman lainya. Guru membiarkan anak menceritakan pengalaman yang dialaminya yang berkaitan dengan materi yang di pelajari dan pertanyaan tersebut ditulis dipapan tulis. Dalam proses pembelajaran terlihat ada beberapa anak yang tidak serius, sibuk bermain sendiri dan sering mengganggu konsentrasi teman lainya yang sedang belajar. Kemudian guru membagi siswa dalam 3 kelompok secara heterogen yang ditinjau dari jenis kelamin dan data kemampuan siswa yang diperoleh saat observasi. Guru terlihat kaku karna belum mengetahui karekteristik semua anak yang ada di dalam kelas sehingga dalam pembagian kelompok guru memerlukan waktu yang cukup lama. Selanjutnya guru masuk pada tahapan "namai" yaitu menjelaskan materi pelajaran dengan menanam dan memuaskan hasrat alami otak, membuat siswa penasaran, penuh pertanyaan mengenai pengalaman pembelajaran macam-macam gerak benda dalam hal ini guru mengajarkan konsep, melatih keterampilan berfikir. Guru memberikan masalah/soal tentang macammacam gerak benda seperti bagaimana delman bisa berjalan? Kenapa sepeda bisa berjalan? Bagaimana perahu layar bisa bergerak? Kenapa bola basket bisa memantul? Dan siswa dirangsang untuk berfikir, kemudian para siswa diberikan kesempatan untuk menjawab. Dalam proses "namai" ini terlihat tidak semua anak menanggapi apa yang diberitahu guru, ada beberapa anak yang tidak fokus pada pembelajaran dan hanya asik sendiri. Selanjutnya guru menjelaskan materi serta meluruskan jawaban dari siswa tentang macam-macam gerak benda, dan menjelaskan sebab benda-benda dapat bergerak yaitu karena mendapat pengaruh dari luar. Seperti contohnya dalam permainan sepak bola, bola dapat bergerak karena di tendang atau dilempar, sepeda dapat melaju karena pedal sepeda dikayuh, perahu layar dapat bergerak karena angin menghembus layar sehingga perahu dapat bergerak.

Tahapan selanjutnya yaitu "rayakan" dilaksankan dengan megajak siswa untuk bernyanyi bersama lagu disini senang disana senang kemudian guru memberikan pujian bagi siswa yang antusias dalam proses pembelajaran, terlihat siswa mengikuti arahan dari guru. Kemudian guru mengkondisikan siswa untuk kembali pada posisi duduknya masing-masing, guru terlihat susah untuk mengatur siswa sehingga membutuhkan waktu. Selanjutnya pada kegiatan akhir para siswa diberikan lembar penilaian untuk mengukur hasil belajar yang diperoleh siswa dalam proses pembelajaran. Hasil belajar IPA tentang gerak benda yang diperoleh dari evaluasi proses pembelajaran dijelaskan pada tabel 1.

Tabel 1. Hasil Belajar Siklus I

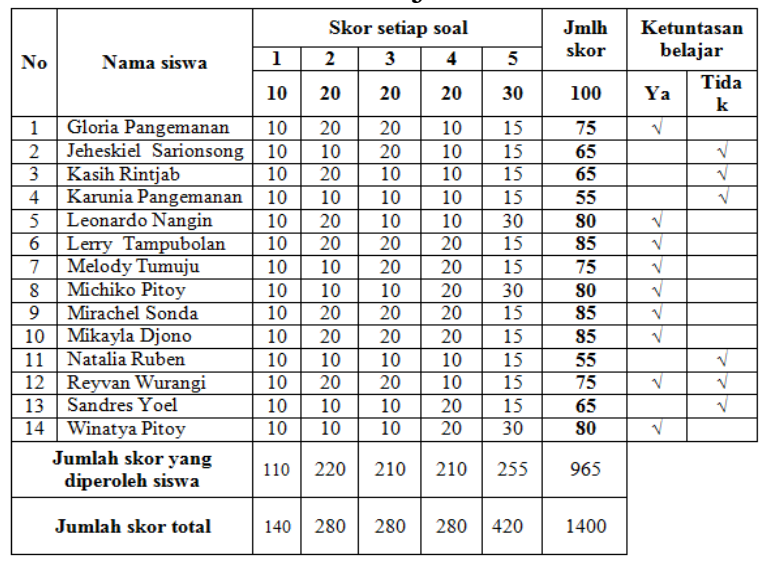

Berdasarkan data pada tabel 1, maka kentutasan belajar yang diperoleh pada siklus 1 adalah sebagai berikut.

$\mathrm{KB}=\frac{\text { Jumlah siswa yang tuntas }}{\text { Jumlah total siswa }} \times 100 \%$
$\mathrm{~KB}=\frac{9}{14} \mathrm{X} 100=64,29 \%$

Jadi pencapaian hasil belajar siswayang diperoleh melalui tes hasil belajar pada siklus I 
yaitu 64,29\%. Pencapaian hasil belajar pada siklus 1 ini belum berhasil meningkatkan hasil belajar siswa karena hasil belajar yang dicapai belum mencapai ketuntasan belajar klasikal yaitu $\geq 75 \%$.Setelah dilihat dari hasil pengamatan yang dilakukan guru pada saat pembelajaran berlangsung ternyata masih terdapat kekuranganya, yaitu peneliti belum berhasil menerapkan langkah-langkah model pembelajaran quantum teaching and learning dengan baik, disamping itu guru belum memahami situasi didalam kelas dengan karakteristik siswa yang berbeda-beda sehingga masih banyak siswa yang kurang aktif dan siswa belum terbiasa dengan model pembelajaran yang diterapkan oleh guru.

Pencapaian hasil belajar siswa melalui tes pada siklus I yaitu 64,29\%. Hasil yang diperoleh ini belum memenuhi kriteria keberhasilan penelitian karena kriteria ketuntasan belajar klasikal yang ditetapkan dalam penelitian ini adalah $\geq 75 \%$. Maka peneliti berusaha melakukan perbaikan pada pembelajaran siklus II yang difokuskan pada langkah-langkah pembelajaran sesuai dengan model pembelajaran quantum teaching and learning, memahami karaktersitik siswa serta mempersiapkan segala sesuatu yang dapat menunjang pembelajaran yaitu rencana pelaksanaan pembelajaran (RPP), media pembelajaran yang relevan yang digunakan dalam penelitian, lembar kerja siswa (LKS), lembar penilaian, pedoman observasi serta kesiapan mental guru maupun kompetensi dalam pelaksanaan tindakan siklus II.

\section{Siklus 2.}

Pada siklus 2 ini, peneliti berkoordinasi dengan guru kelas untuk menyusun perbaikan strategi dan rencana proses pembelajaran menggunakan model pembelajaran quantum teacing and learning dan selanjutnya peneliti menyiapkan materi ajar dan media pembelajaran serta alat evaluasi seperti lembar observasi, LKS dan lembar penilaian. Dari hasil observasi pelaksanaan tindakan siklus 2 diuraikan sebagai berikut.

Kegiatan pembelajaran siklus ke-2 ini dimulai dengan guru membuka pembelajaran dengan salam dan doa, guru menunjuk salah satu murid untuk memimpin doa, kemudian guru menumbuhkan minat dengan menayangkan video motifasi belajar kemudian menyanyi bersama lagu "naik kereta api" dilanjutkan dengan guru menyampaikan tujuan pembelajaran yaitu siswa dapat menyebutkan dan memberikan contoh tentang macam-macam gerak benda.

Guru kemudian masuk pada kegiatan inti pembelajaran yang dimulai dengan menumbuhkan sifat "alami" yaitu guru bertanya kepada siswa tentang gerak benda sesuai dengan pengalaman siswa seperti naik delman, bermain bola, menaiki lucuran dan pengalaman lainya guru membiarkan anak menceritakan pengalaman yang dialaminya yang berkaitan dengan materi yang akan di pelajari dan pertanyaan tersebut ditulis dipapan tulis terlihat anak-anak serius mengikuti pembelajaran. Kemudian guru membagi siswa dalam 3 kelompok secara heterogen, guru terlihat menguasai karna sudah mengetahui karakteristik dari setiap anak. Selanjutnya guru menjelaskan materi yang dimulai dari "namai" yaitu menjelaskan materi pelajaran dengan menanam dan memuaskan hasrat alami otak dan membuat siswa penasaran serta penuh pertanyaan mengenai pengalaman pembelajaran macammacam gerak benda. Dalam hal ini guru mengajarkan konsep, melatih keterampilan berfikir dengan memberikan masalah/soal tentang macam-macam gerak benda seperti permainan bola bagaimana bola bisa berpindah dari teman yang satu ke teman lainya?, kenapa sampah bisa mengalir disungai?, kenapa bola basket dapat memantul?, dan siswa diminta untuk berfikir kemudian diberikan kesempatan pada siswa untuk menjawab. Pada tahapan ini terlihat semua anak menanggapi apa yang diberitahu 
guru. Selanjutnya guru menjelaskan materi serta meluruskan jawaban dari siswa tentang macam-macam gerak benda, dan penyebab benda bergerak yaitu karena mendapat pengaruh dari luar. Guru menjelaskan bahwa benda dapat bergerak jika ada dorongan atau tarikan yang memengaruhi benda tersebut. Guru terlihat baik dalam penjelasan semua dan siswa memperhatikan dengan baik.

Setelah guru menjelaskan materi kemudian guru dan siswa mempraktekan macam-macam gerak benda dengan menggunakan media alat peraga yang sudah disiapkan guru seperti bola, kelereng, styrofoam, ember besar yang dipenuhi air.Siswa terlihat antusias untuk melakukan percobaan yang dibimbing guru, guru terlihat baik saat menjelaskan dalam tahap percobaan. Tahap yang dilakukan selanjutnya yaitu "demonstrasi" diawali dengan memberikan soal LKS kepada setiap kelompok, dan guru memberikan waktu untuk mengerjakan soal tersebut. Setelah itu guru mengawasi kelompok, terlihat guru sudah menguasai semua kelompok kemudian setelah semua kelompok selesai, perwakilan setiap kelompok bergantian maju. Tahap selanjutnya yaitu "ulangi" guru memberikan ulangan tentang apa yang sudah dipelajari sebelumnya guru membuat tulisan di papan tulis dengan isian "aku tahu bahwa aku tahu ini" agar siswa mengigat semua apa yang telah di pelajari dan yang telah di demontrasikan, kemudian guru memberikan pertanyaan kembali bagaimana proses benda bisa bergerak? Kenapa delman bisa bergerak? Apa yang mempengeruhi benda bergerak? Terlihat siswa tertarik pada pertanyaan yang diberikan guru. Kemudian guru meluruskan jawaban siswa yang kurang tepat terlihat disini guru baik dalam meluruskan jawaban siswa. Tahapan selanjutnya yaitu "rayakan" tahap ini dituangkan pada ahir pembelajaran dengan maksud memberikan rasa puas dan menghormati usaha, ketekunan, dan kesuksesan yang memberikan rasa kepuasan dan kegembiraan, bernyanyi bersama lagu disini senang disana senang kemudian guru memberikan pujian bagi siswayang antusias dalam proses pembelajaran, terlihat siswa mengikuti arahan dari guru. Kemudian guru mengkondisikan siswa untuk kembali pada posisi duduknya masing-masing. Guru membagikan lembar evaluasi kepada seluruh siswa untuk dikerjakan secara individu setelah siswa selesai mengerjakan soal evaluasi guru mengumpulkan soal yang terisi. Kemudian kegiatan diakhiri guru dengan membimbing siswa untuk membahas jawaban soal evaluasi serta dilanjutkan dengan pemberian motivasi belajar dari guru kemudian menutup kegiatan pembelajaran dengan menunjuk salah satu siswa untuk maju kedepan dan memimpin siswa untuk berdoa pulang.Hasil evaluasi proses pembelajaran siklus kedua yang diperoleh dari tes hasil belajar dijelaskan pada tabel 2.

Tabel 2. Hasil Belajar Siklus II

\begin{tabular}{|c|c|c|c|c|c|c|c|c|c|}
\hline \multirow{3}{*}{ No } & \multirow{3}{*}{ Nama siswa } & \multicolumn{5}{|c|}{ Skor setiap soal } & \multirow{3}{*}{ 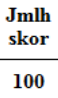 } & \multirow{2}{*}{\multicolumn{2}{|c|}{$\begin{array}{c}\text { Ketuntasan } \\
\text { belajar }\end{array}$}} \\
\hline & & \multirow{2}{*}{$\begin{array}{c}1 \\
10\end{array}$} & \multirow{2}{*}{$\begin{array}{c}2 \\
20\end{array}$} & \multirow{2}{*}{$\begin{array}{c}3 \\
20\end{array}$} & \multirow{2}{*}{$\begin{array}{c}4 \\
20\end{array}$} & \multirow{2}{*}{$\begin{array}{c}5 \\
30\end{array}$} & & & \\
\hline & & & & & & & & $\mathbf{Y a}$ & $\begin{array}{c}\text { Tida } \\
\mathbf{k}\end{array}$ \\
\hline 1 & Gloria Pangemanan & 10 & 20 & 20 & 10 & 30 & 90 & $\sqrt{ }$ & \\
\hline 2 & \begin{tabular}{|l|} 
Jeheskiel Sarionsong \\
\end{tabular} & 10 & 10 & 20 & 10 & 15 & 65 & & $\sqrt{ }$ \\
\hline 3 & \begin{tabular}{|l|} 
Kasih Rintjab \\
\end{tabular} & 10 & 20 & 10 & 10 & 30 & 80 & $\sqrt{ }$ & \\
\hline 4 & Karunia Pangemanan & 10 & 20 & 20 & 20 & 15 & 85 & $\sqrt{ }$ & \\
\hline 5 & Leonardo Nangin & 10 & 20 & 10 & 20 & 30 & 90 & $\sqrt{ }$ & \\
\hline 6 & Lerry Tampubolan & 10 & 20 & 20 & 20 & 30 & 100 & $\sqrt{ }$ & \\
\hline 7 & Melody Tumuju & 10 & 20 & 20 & 20 & 15 & 85 & $\sqrt{ }$ & \\
\hline 8 & \begin{tabular}{|l} 
Michiko Pitoy \\
\end{tabular} & 10 & 20 & 10 & 20 & 30 & 90 & $\sqrt{ }$ & \\
\hline 9 & Mirachel Sonda & 10 & 20 & 20 & 20 & 30 & 100 & $\sqrt{ }$ & \\
\hline 10 & Mikayla Djono & 10 & 20 & 20 & 20 & 15 & 85 & $\sqrt{ }$ & \\
\hline 11 & Natalia Ruben & 10 & 20 & 10 & 20 & 30 & 90 & $\sqrt{ }$ & \\
\hline 12 & Reyvan Wurangi & 10 & 20 & 20 & 20 & 15 & 85 & $\sqrt{ }$ & \\
\hline 13 & \begin{tabular}{|l|} 
Sandres Yoel \\
\end{tabular} & 10 & 10 & 10 & 20 & 15 & 65 & & $\sqrt{ }$ \\
\hline 14 & \begin{tabular}{|l|} 
Winatya Pitoy \\
\end{tabular} & 10 & 20 & 20 & 10 & 30 & 90 & $\sqrt{ }$ & \\
\hline & $\begin{array}{l}\text { Jumlah skor yang } \\
\text { diperoleh siswa }\end{array}$ & 135 & 270 & 230 & 240 & 330 & 1205 & & \\
\hline & Jumlah skor total & 140 & 280 & 280 & 280 & 420 & 1400 & & \\
\hline
\end{tabular}

Berdasarkan data pada tabel 2, maka ketuntasan belajar yang diperoleh pada siklus 2 adalah sebagai berikut.

$$
\begin{aligned}
& \mathrm{KB}=\frac{\text { Jumlah Siswa yang tuntas }}{\text { Total siswa yang tuntas }} \times 100 \% \\
& \mathrm{~KB}=\frac{12}{14} \times 100=85,71 \%
\end{aligned}
$$

Jadi pencapaian hasil belajar siswayang diperoleh melalui tes hasil belajar pada siklus 2 yaitu $85,71 \%$. Pencapaian hasil belajar pada siklus 2 ini telah berhasil meningkatkan hasil belajar siswa karena hasil belajar yang dicapai 
telah mencapai ketuntasan belajar klasikal yaitu $\geq 75 \%$.

Setelah guru selaku peneliti melakukan pembelajaran, hasil yang dicapai pada siklus II ini yaitu $85,71 \%$ itu artinya presentase ketuntasan belajar sudah tercapai. Penggunaan model quantum teaching and learning tidak lagi mengalami hambatan, guru telah menerapkan langkah-langkah quantum teaching and learning dengan baik, guru mulai memahami karakteristik siswa dalam kelas. Kegiatan pembelajaran berlangsung dengan baik, siswa mampu bekerja sama dengan teman kelompoknya, sehingga tugas yang diberikan dapat diselesaikan dan ahirnya siswa dapat menyelesaikan tugas pada lembar penilaian.

Pencapaian hasil belajar pada siklus II adalah $85,71 \%$, hal ini menunjukan ketuntasan belajar yang dicapai telah mencapai kriteria keberhasilan penelitian. Dengan demikian dapat dikatakan bahwa telah terjadi peningkatan pada hasil belajar siswa dalam pembelajaran macam-macam gerak benda dikelas III SD INPRES 4/82 Walian dengan menggunakan model quantum teaching and learning. Berdasarkan hasil ketuntasan belajar yang telah dicapai yaitu $85,71 \%$ maka tindakan pada siklus II dinyatakan berhasil dan tidak perlu dilanjutkan pada siklus berikutnya.

\subsection{Pembahasan}

Dalam kegiatan pembelajaran siswa diupayakan mencapai tujuan pembelajaran, namun melihat kondisi yang terjadi tidak sesuai seperti yang diharapkan. Pada kegiatan belajar mengajar di siklus I, ketuntasan belajar siswa hanya mencapai 64,29\%. Hal ini disebabkan peneliti belum berhasil menerapkan langkah-langkah model pembelajaran quantum teaching and learning dengan baik, selain itu peneliti tidak mengontrol siswa didalam kelas selama melakukan percobaan sehingga banyak siswa yang hanya bermain-main dengan teman- teman kelompoknya, serta peneliti belum memahami situasi didalam kelas dengan karakteristik siswa yang berbeda-beda yang berdampak pada hasil belajar siswa belum mencapai ketuntasan belajar klasikal yaitu $\geq 75 \%$. Peran peneliti sangat penting dalam mengupayakan proses pembelajaran yang lebih bermakna sehingga dapat meningkatkan hasil belajar siswa.

Pada siklus II, hasil belajar siswa telah mengalami peningkatan dari $64,29 \%$ di siklus I menjadi $85,71 \%$ di siklus II. Pada siklus yang kedua pencapaian hasil belajar mengalami peningkatan karena peneliti berhasil melakukan perbaikan pada penerapan model pembelajaran quantum teaching and learning, menguasai kelas, dan memahami kondisi siswa. Keberhasilan ini juga dicapai karena peneliti berhasil memperbaiki kekurangan-kekurangan yang di alami dalam pembelajaran di kelas, ini terlihat dari siswa sangat aktif ketika peneliti memberikan LKS yang di kerjakan secara kelompok, begitu juga dengan soal individu yang di berikan peneliti diakhir pembelajaran dikerjakan oleh siswa dengan serius.

Penelitian yang menggunakan model quantum teaching and learning ini mengikuti langkah pembelajaran tandur yang dikemukakan Deporter (2010:37). Pada langkah pertama yaitu tumbuhkan, pemberian motivasi dengan kalimat pernyataan "kamu pasti bisa" mampu menumbuhkan minat belajar sehingga siswa menjadi semangat dalam pembelajaran yang berlangsung.

Proses pembelajaran yang menerapkan model pembelajaran quantum teaching and learning tipe tandur ini, pada tahapan "alami" memberikan kesempatan pada siswa untuk mengemukakan pengalaman pribadinya yang berhubungan dengan materi pembelajaran. Dengan melibatkan pengalaman maka siswa lebih mudah memahami serta mengikuti pembelajaran yang dibelajarkan. Tahapan ini adalah bagian dari perwujudan asas model pembelajaran quantum yaitu "bawalah dunia 
mereka ke dunia kita, dan hantarkan dunia kita ke dunia mereka", namun pembelajaran yang melibatkan pengalaman pribadi anak seringkali mengalami kesulitan karena perbedaan setiap siswa, sehingga terkadang pengalamn yang dikemukan anak agak berbeda dengan konsep materi yang diajarkan (Budde et, al; 2002, 197). Oleh sebab itu kesulitan belajar dan karakteristik siswa sangat penting untuk diperhatikan dan dianalisis oleh guru yang menerapkan pembelajaran quatum teaching and learning tipe tandur ini. Hal ini ditemukan dalam penelitian ini yaitu pada siklus pertama guru belum menguasai kelas dan memahami karakteristik siswa menyebabkan para siswa tidak focus dalam pembelajaran sehingga pencapaian hasil belajar siklus 1 tidak optimal, sementara pada siklus kedua guru telah mampu mengusai kelas dan memahami karakteristik siswa sehingga penerapan model pembelajaran quantum teaching and learning ini mampu membuat pencapaian hasil belajar IPA materi gerak benda mengalami ketuntasan klasikal.

Pencapaian hasil belajar yang optimal dapat diraih jika guru mampu menerapkan langkah-langkah pembelajaran dari model pembelajaran Quantum Teaching and Learning tipe tandur dengan benar.Pada langkah "namai" guru membuat siswa menjadi penasaran dengan berbagai pertanyaan atau masalah sehingga meransang siswa untuk berpikir kreatif. Hal ini juga merupakan temuan dari penelitian yang terjadi pada siklus kedua dimana ketika guru menanamkan konsep dengan menggunakan media pembelajaran yang tepat sehingga menarik perhatian siswa, mereka mampu mendemonstrasikan materi yang telah diajarkan serta mengulangi dan menjelaskan kembali materi yang telah diajarkan yaitu materi gerak benda yang akhirnya menjadi sebuah pengetahuan baru yang telah dibangun oleh siswa itu sendiri lewat pengalamannya yang diperoleh dari proses pembelajaran. Hal ini sejalan dengan hasil penelitian Johnston et,al. (2007:443) yang berjudul "Student difficulties in learning quantum mechanics, dimana menjelaskan bahwa pengetahuan secara perlahan dibangun melalui proses pembelajaran dari konsep yang merupakan pengalamannya.

Tahapan pembelajaran yang terahir dari model pembelajaran quantum teaching and learning yaitu "rayakan" merupakan bentuk penghargaan bagi setiap usaha dan semangat belajar para siswa yang dilaksankan dengan memberikan pujian sehingga menumbuhkembangkan semangat dan motivasi belajar seperti yang jelaskan oleh Burden (2000: 64) bahwa siswa termotivasi untuk belajar ketika mereka berharap menjadi sukses, dan perbedaan siswa begitu beragam sehingga beberapa siswa membutuhkan lebih banyak motivasi dan pujian daripada yang lain, sementara siswa lain membutuhkan lebih banyak penguatan dan pujian sehingga lebih termotivasi untuk belajar daripada yang lain.

Inti keberhasilan dari model quantum adalah kepribadian yang dewasa dari siswa itu sendiri atau siswa yang memiliki motivasi dan semangat belajar. Jika terdapat siswa yang kurang memiliki motivasi belajar dalam proses pembelajaran maka ia harus memperbaikinya agar dapat berkontribusi pada berbagai penyelesaian masalah dan berhasil mencapai tujuan pembelajaran (Selby 1999:137). Hal ini telah dibuktikan Sachs (2008:21) dalam Millennium Village Project dimana kemauan yang tinggi untuk belajar, berlatih, mampu membuat mereka bekerja keras dan meningkatkan ketrampilan melalui proses pembelajaran, sehingga sekarang mereka memiliki kemampuan merawat anak dan orang tua yang dahulunya tidak mereka miliki. Uraian diatas menunjukan bahwa motivasi belajar merupakan bagian penting dari penerapan model pembelajaran quantum teaching and learning untuk mencapai hasil belajar yang optimal. Namun dalam penelitian ini, motivasi belajar tidak dibahas secara mendalam. 
Dari hasil dan temuan penelitian serta pembahasan dapat disimpulkan bahwa penerapan model pembelajaran Quantum Teaching and Learning dapat meningkatkan hasil belajar IPA siswa kelas III SD Inpres 4/82 Walian.

\section{Kesimpulan}

Berdasarkan hasil penelitian dan pembahasaan maka dapat disimpulkan bahwa penerapan model pembelajaran Quantum Teaching and Learning dapat meningkatkan hasil belajar IPA siswa kelas III SD Inpres 4/82 Walian, dimana dalam pembelajaran ini siswa di buat penasaran dan guru menghantarkan siswa dengan situasi yang membawa dunia mereka ke dalam dunia kita dan menghantarkan dunia kita ke dalam dunia mereka, sehingga meningkatkan minat belajar yang bersinergi pada peningkatan hasil belajar.

\section{Daftar Pustaka}

Acat MB, Yusuf AY. An inve stigation the effect of quantum learning approach on primary school 7th grade students' science achievement, retention and attitude. The International Journal of Research in Teacher Education. 2014;5(2):11-23

Budde M, Niedderer H, Scott P, Leach J. 'Electronium': a quantum atomic teaching model. Physics Education. 2002 Mei;37(3): 197

Burden PR. Powerful classroom management strategies: Motivating students to learn. Corwin Press; 2000 Mar 14

De Porter, Mark Reardon, Sarah SingerNouri. Quantum Teaching Learning.Mempraktikkan quantum learning di ruang-ruang kelas. Bandung: Kaifa Perpustakaan Nasional. 2010.
Dewi GA, Suarni NK, Widiana IW. Pengaruh Model Pembelajaran Tandur Terhadap Hasil Belajar IPA Ditinjau Dari Minat Belajar Siswa.MIMBAR PGSD Undiksha. 2014 Aug 5;2(1).

Hanbay, O. (2009). Kuantum Öğrenme Temelli Öğreterek Öğrenme Yönteminin İkinci Yabancı Dil Olarak Almancanın Öğrenilmesine Etkisi, Dicle Üniversitesi Ziya Gökalp Eğitim Fakültesi Dergisi,1(12), 17-27.

Johnston ID, Crawford K, Fletcher PR. Student difficulties in learning quantum mechanics. International Journal of Science Education. 1998 Apr 1;20(4):427-446.

Lucas, T., Villegas, A. M., \& FreedsonGonzalez, M. (2008). Linguistically responsive teacher education:

Preparing classroom teachers to teach English language learners. Journal of Teacher Education, 59(4), 361-373.

Makmun, Abin Syamsudin. Psikologi

Kependidikan. Bandung: Rosdakarya. 2007.

Selby D. Global Education: Towards a Quantum Model of Environmental Education. Canadian Journal of Environmental Education. 1999; 4:125-141

Sachs J. The end of poverty: economic possibilities for our time. European Journal of Dental Education. 2008 Feb;12:17-21.

Sumilat J. M. Pemanfaatan Media Pembelajaran Matematika Interaktif Untuk Meningkatkan Hasil Belajar Siswa di SD Negeri 2 Tataaran. Jurnal Inventa. 2018 Apr 3; 2(1): 40-46

Syah Muhibin. Psikologi Pendidikan. Bandung: Rosdakarya.2011. 
